\title{
FINANCING DEFENSE CONTRACTS
}

\author{
E. K. GubiN*
}

INTRODUCTION

As defense spending continues to spiral in our national economy, more and more of industry must become involved in defense contracts. Newcomers to the government contract field seem to believe that once they secure a contract, money. flows from Uncle Sam in a steady and uninterrupted stream. Such is far from true. This article will place in proper perspective the position of the federal government in the financing of defense contracts.

The Bible of defense financing is a roo-page section of the appendices found in the Armed Services Procurement Regulation (ASPR), titled Appendix E, "Defense Contract Financing Regulations." All references to sections herein, unless otherwise designated, will be to that important document.

\section{Preliminary Considerations}

\section{A. Contractor Should Be Financially Responsible}

Normally, government contracts will be awarded only to those contractors who are capable of performance, and who qualify under the six ASPR minimum standards for responsible prospective contractors, ${ }^{1}$ the first of which requires that the contractor "have adequate financial resources, or the ability to obtain such resources as required during performance of the contract." These words would seem to rule out government financing, except that Appendix E of ASPR is referenced immediately after the words mentioned above.

\section{B. Government Financing No Handicap}

Turning to Appendix $\mathrm{E}$ we find ${ }^{2}$ that a contractor who is ordinarily deemed reliable, competent, capable, and otherwise responsible, will not be any less responsible by reason of the need for reasonable contract financing, provided or guaranteed by a military department. This does not mean that the government will willy-nilly finance a contractor who wishes to become a defense contractor. Instead, we find that Appendix $E$ has a number of sections ${ }^{3}$ which explain the

*A.B. 1926, LL.B. 1928, University of California. Instructor in Government Contract Law, George Washington University, and USDA Graduate School, School of Logistics, Ohio State University, Member of the Supreme Court of the United States, the Court of Appeals, District of Columbia, and the California bars.

${ }^{1}$ ASPR I-903.I, Appendix E, 32 C.F.R. $\$$ I.903-I (I963).

${ }^{2} I d . \S 210,32$ C.F.R. $\$ 163.23$ (I96r).

${ }^{3} I d$. $\$ \$ 212-214,32$ C.F.R. $\$ 163.26-163.28$ (I96r). 
amount of investigation and coordination which takes place prior to contract award, concerning whether financing can be prudently arranged for the contractor.

It should be noted that the contracting officer is chargeable with ascertaining, prior to contract awards, that financing for performance of these contracts is reasonably assured prior to or contemporaneous with the making of contracts." Thus, even before a contract is awarded, financing problems are normally brought up; and if the contractor has no private banking sources, it is quite possible that government financing can be made available to come into existence contemporaneously with the contract award.

\section{Non-indication of Contract Financing Prior to Award}

The fact that a contractor did not indicate before award that he would require contract financing, or that he stated he would not require such financing, does not disqualify him for proper contract financing after award. ${ }^{5}$ Circumstances often change after the date of the award of a contract; and the regulations readily recognize this, but direct that each case be decided on its own individual merits, regardless of the contractor's original error concerning need for financing.

\section{Order of Financing Precedence}

The following order of precedence will normally be observed in determining what form of financing should be recommended or made available to suppliers: ${ }^{6}$

I. private financing on reasonable terms, without government guarantees (but often with "assignment of claim" to bank);

2. customary progress payments;

3. government guaranteed loans, with financing institutions participating to an extent appropriate to the risk involved; ${ }^{8}$

4. unusual progress payments; ${ }^{9}$

5. advance payments. ${ }^{10}$

Each of these financing forms will be discussed in the following sections of this article.

\section{II}

\section{Private Financing Without Government Guaranté or Participation}

\section{A. Pre-rg40 Problems}

Prior to 1940 , it was discovered that bank loans where government contracts were used as collateral were difficult to obtain because of the law then in effect that

'Id. $\$ 212,32$ C.F.R. $\S 163.26$ (I961).

IId. $\$ 210.1,32$ C.F.R. $\$ 163.23$-I (196r).

${ }^{\circ} I d . \$ 209,32$ C.F.R. $\$ 163.22$ (I96r).

${ }^{7} I d . \$ 503,32$ C.F.R. $\$ 163.72$ (I96r).

${ }^{8}$ Id. $\$ \$ 301-304,32$ C.F.R. $\$ \$ 163.35-163.38$ (1961).

${ }^{0}$ Id. $\$ 505,32$ C.F.R. $\$ 163.74$ (196I).

${ }^{10}$ Id. $\$ 408,32$ C.F.R. $\$ 163.58$ (I96r). 
assignment of monies paid by the government to a contractor was prohibited under earlier statutes. ${ }^{11}$

\section{B. Assignment of Claims Act of 1940}

The Act of 1940 , as amended, ${ }^{12}$ not only allowed assignment of government contract proceeds but permitted the so-called "no set-off" provision in military contracts, whereby payments to an assignee under such contracts are exempted from set off or reduction for any indebtedness of the assignor to the government arising independently of such contracts.

r. Thus, setoffs for the assignor's liability on account of renegotiation, fines, penalties, taxes or social security contributions are forbidden.

2. The term "penalties," however, does not include amounts which may be withheld from the assignee in accordance with, or for failure to comply with, terms of the contract, including setoffs for violation of the minimum wage or other wage laws, liquidated or other damages for failure to perform the contract, or reductions under price redetermination provisions.

\section{III}

\section{Customary Progress Payments}

Ordinarily, payments are prohibited prior to the delivery of supplies or services to the government. ${ }^{13}$ However, the Comptroller General has ruled that payments may be made for articles in advance of actual delivery if title therein is vested in the government at the time of payment. ${ }^{14}$

\section{A. Partial vs. Progress Payments}

In various sections of ASPR references are made to "partial" payment. For example, this appears in the termination clauses. Such payments will not be discussed herein; instead this discussion will concern progress payments of the type indicated below, which in effect are payments to reimburse a contractor for a part of the costs incurred during the period of performance of the contract. At that point the contractor (absent an appropriate clause) is not entitled to any immediate reimbursement because the work, for which the costs were incurred, is not yet ready for delivery to the government. Therefore a clause must be placed in the contract to allow reimbursement for at least a portion of the costs incurred during the progress of the work.

${ }^{11} 54$ Stat. 1029 (1940), as amended, 4I U.S.C. $\$$ I5 (1958); 35 Stat. 4II (1908), as amended, 3I U.S.C. $\$ 203$ (1958).

${ }^{22} 35$ Stat. 4II (rgo8), as amended, 3I U.S.C. \$ 203 (1958); 54 Stat. 1029 (1940), as amended, 4I U.S.C. $\$ 15$ (1958), ASPR 7-103.8, 32 C.F.R. $\$ 7.103-8$ (196r).

${ }^{13} 60$ Stat. 809 (1946), 3I U.S.C. $\$ 529$ (1958).

16 20 Decs. Comp. Gen. 917 (I94I). All progress payment clauses provide that "title to all parts, materials," and so on, chargeable to the contract, "shall forthwith vest in the government ...." ASPR Appendix E, $\$ 5$ Io.i(d), 32 C.F.R. $\$ 163.79-1(d)$ (rg6r). 
B. Payments Based on Percentage of Stage of Completion

Except for construction and shipbuilding, progress payments based on a percentage or stage of completion of the item are no longer used, ${ }^{15}$ even though logically the best measure of the value of what the government is gaining would be the percent of completion.

\section{Progress Payments Based on a Percentage of Costs}

The preferred progress payments currently used are those based on a percentage of costs (preferably on a percentage of total costs). Normally those costs are not more than seventy per cent of total costs, or eighty-five per cent of direct labor and material costs of the work done under the undelivered portion of a contract, except that for certain small business contracts these percentages may be seventy-five per cent of total costs, or ninety per cent of direct labor and material costs. ${ }^{16}$ Certain standards have been established ${ }^{17}$ for use of progress payment clauses which are really based on tradition and custom, in industry and government:

I. Such clauses appear in contracts involving long lead time or preparatory period, usually six months or more; examples include aircraft, engines, and complex electronic equipment.

2. Contracts for quick turnover items will not be covered by the clause, ${ }^{18}$ on the ground that such a rule follows industry custom; these items include subsistence, clothing and apparel, off-the-shelf items, and standard commercial items.

\section{Applicable to Either Negotiated or Advertised Contracts}

Originally progress payments were restricted to negotiated contracts. Under current policy, advertised procurements and invitations for bids (IFB) can also be the subject of progress payments, but there are certain rules to be followed:

r. If the contracting officer considers progress payments should be limited to small business exclusively, the invitations for bids will so state. ${ }^{19}$

2. The invitation for bids itself must mention that progress payments will be allowed under the specific procurement. ${ }^{20}$

3. Even if the invitation for bids allows progress payments, such a provision will

${ }^{15} I d . \S 501,32$ C.F.R. $\$ 163.70$ (I96I).

${ }^{10} I d . ~ \$ \$ 503-504,32$ C.F.R. $\$ \$ 163-72-163.73$ (I96I). Subcontractors can secure progress payments from primes under the same conditions and circumstances that primes secure such payments from the govcrnment. $\S 515,32$ C.F.R. $\S 163.84$ (196r). This is so even though the prime has a cost-reimbursement contract which traditionally is not subject to progress payments to prime for prime's own direct costs. $\S 500.2,32$ C.F.R. $\$ 163.69-2$ (I96x); $\S 5 \mathrm{I} 4,32$ C.F.R. $\$ 163.83$ (Ig6r). The prime is of course reimbursed by the government. \$513.I, 32 C.F.R. $\$ 163.82-\mathrm{I}$ (I96r).

I8 Id. App. E, $\S 503,32$ C.F.R. $\$ 163.72$ (I96I). See $\$ 5$ Io, 32 C.F.R. $\$$ I63.79 (I96I), for appropriate contract clause.

${ }^{18} I d$. App. E, $\S 504 . \mathrm{T}, 32$ C.F.R. $\S \mathrm{x} 63.73-\mathrm{I}$ (196r).

${ }^{10} 1 d$. App. E, $\$ 504.3,32$ C.F.R. $\$ 163.73-3$ (196r).

${ }^{20}$ Id. App. E, $\$ 504.4,32$ C.F.R. $\$ 163.73-4$ (196I). 
not be automatically included in an awarded contract unless the contractor actually requests this in his bid. ${ }^{21}$

4. If the invitation for bids does not authorize progress payments, such a clause cannot be later included in the contract at the time of award; and bids conditioned upon provisions for progress payments will be rejected as nonresponsive. $^{22}$

5. When the invitation for bids provides progress payments for small business concerns exclusively, progress payment provision cannot be made for contractors who are not small business concerns; and bids of those who are not small business concerns conditioned upon provision for progress payments will be rejected as nonresponsive. ${ }^{23}$

\section{IV}

\section{Unusual Progress Payments}

Progress payments other than those of the class set out in section three herein [i.e., in excess of eighty-five per cent of direct labor and material costs, or seventy per cent of total costs] are regarded as unusual, and require special approval. Exceptional circumstances must exist for such approval, which is normally by the head of a procuring activity, or a general or flag officer designated for that purpose. ${ }^{24}$ Among the things a contractor seeking unusual payments will be required to demonstrate are the following:

I. That his contract involves a preparatory period requiring pre-delivery expenditures that are large in relation to the contract price and to the contractor's working capital and credit.

2. That progress payments in this category will be only supplementary to private financing, including guaranteed loans.

3. That the percentage rates and cost bases for progress payments on new procurement in this category will be determined on a minimum basis commensurate with the contractor's production schedule requirements and minimum inventory lead time, with due regard to the contractor's projected cash needs, cash resources, and their planned application.

${ }^{21}$ Ibid.

${ }^{22}$ Id. App. E, $\S 504.6,32$ C.F.R. $\$ 163.73-6$ (196I). However, a modification of the contract can be entered into after contract award which will allow progress payments, but in such event the contractor must provide some consideration for the modification, such as a slight price reduction. Sec Garod Radio Corp. v. United States (Ct. Cls. 1962), 8 CCF I 71,890, where the price reduction was $1 \%$. As an indication of the confusion in terminology, note that the Court of Claims decision discusses "advance partial payment" while CCF calls it "partial progress payments."

${ }^{23}$ Id. App. E, \$ 504.6, 32 C.F.R. \$ $163.73-6$ (I96r).

${ }^{24}$ Id. App. E, $\$ 505,32$ C.F.R. $\$ 163.74$ (196I); ASPR I-20I.4, 32 C.F.R. $\$ 1.201-4$ (196r). 


\section{Loans by Financing Institutions Guaranteed by the Government}

A. The Law

Under section 302(b) of Executive Order No. I0480, promulgated pursuant to section 30r (b) of the Defense Production Act of I950, as amended, Federal Reserve Banks act as fiscal agents ${ }^{25}$ of the United States in making contracts of guarantee concerning guaranteed loans for private financing institutions. ${ }^{26}$ The operations of the Federal Reserve System are governed by Regulation V of the Board of Governors of the Federal Reserve; hence the popular designation of "V Loans," which were used so often during World War II.

\section{B. The Rules}

The various rules pertaining to these guaranteed loans are covered in ASPR Appendix $\mathrm{E}$ in rather technical language, but the following sections will clearly indicate the guidelines established by the rules.

\section{Eligibility Tests}

Not all contracts are subject to a guarantee. A guarantee is possible where the contract is held by a prime contractor (or even a subcontractor at any level), only if the guaranteeing agency satisfies itself and can certify ${ }^{27}$ that:

I. The product or service covered by the contract is essential to the national defense.

2. The material or services cannot readily be obtained from an alternative source without injury to the national defense.

3. The contractor has the technical ability and required facilities to perform the contract.

\section{Loan Highlights- $-V$ Loans from Commercial Banks}

In deciding whether or not a contractor should accept his bank's suggestion to participate in the $\mathrm{V}$ Loan program, he should give consideration to these principal facts:

I. Guarantees are made primarily for the purpose of providing working capital. The V Loan is not generally used for plant expansion, for even though such use is not prohibited by law, the Armed Services have a policy against it. ${ }^{28}$

2. The maximum amount loaned to any individual or firm is not limited by statute. The amount loaned is solely a question of need and a decision by the

${ }^{25} 64$ Stat. 800 (I950), as amended, 50 U.S.C. App. $\$ 209 \mathrm{r}$ (b) (I958), x8 Fed. Reg. 4939 (I953). Besides acting as fiscal agents, Federal Reserve Banks can also make guaranteed loans themselves. See ASPR, App. E, $\S 304,32$ C.F.R. $\S 163.38$ (I96r).

${ }^{30}$ Id. App. E, $\$ 30 \mathrm{r}, 32$ C.F.R. $\$ 163.35$ (I96r).

${ }^{27} I d$. App. E, $\$ 314,314.1,32$ C.F.R. I63.48 (I96I).

${ }^{38}$ Id. App. E, $\S 308,32$ C.F.R. $\S 163.4 \mathrm{r}$ (r96r). 
government as to the amount the financial condition of the company warrants. ${ }^{28}$

3. The Federal Reserve Banks are the central point of government contact on $\mathrm{V}$ Loans. As in World War II, these banks have been designated as fiscal agents of the government on $\mathrm{V}$ Loans, and all requests for assistance and notification of approval are funneled through these banks by the contractor's financial institution.

4. Interest rates chargeable by banks on loans to be guaranteed cannot exceed six per cent. The government will not guarantee higher interest rate loans. This action is taken under provisions of law which authorize the Federal Reserve Board, after consulting the guaranteeing agencies, to prescribe fees and other charges which may be made by financing agencies in connection with V Loans.

5. The guarantee can cover part or, in exceptional circumstances, all of the loan. Depending on circumstances, the guarantee may run from fifty per cent to one hundred per cent, but the full one hundred per cent is extremely rare. ${ }^{30}$

6. Guarantees usually are made only in connection with sound risks. Except for the exigencies of national defense, as determined by the guaranteeing agency, the government normally will not handle extremely risky loans; it relies upon the Federal Reserve Bank to a great extent in making a thorough investigation of all the facts incidental to the application.

7. The charge the government makes for guaranteeing a loan varies with the proportion of the loan guaranteed. This guarantee fee is paid by the lending bank out of the interest collected on the loan.

8. Small business enterprises have just as good an opportunity to obtain guarantees as large firms. V Loan regulations provide for special consideration for the needs of small business.

\section{E. Steps in Getting Loan}

Now assume that, after considering all these factors, the contractor decides to accept his banker's advice and apply for a V Loan guarantee. Remember that it is the bank, not the contractor, that really decides whether to apply for a guarantee, and it is the bank, not the contractor, that physically makes the application. With this in mind, here are the steps ${ }^{\mathbf{3 1}}$ which must be taken by the contractor's bank and the government agencies involved:

I. Application to local bank. The contractor goes to his local bank or financing institution, requests a loan, works out the loan arrangement, and fills in the necessary papers required in connection with a guaranteed loan. At this time, he should work out necessary details as to the amount of money needed, interest rate, percentage of loan to be guaranteed, and other relevant problems. Then he sits tight and waits for the bank to notify him of accept-

${ }^{20}$ Id. App. E, $\$ 309,32$ C.F.R. § 163.42 (r96r).

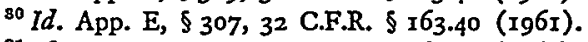

${ }^{31}$ Id. App. E, \$ 303, 32 C.F.R. \$ 163.36 (I96I). 
ance or rejection. Of course, it will not hurt his case to let the particular Armed Services buying official who is handling his government contract know of his problems, because this official will assist in making the decision as to whether the contract is eligible for a guarantee. But the contractor should not badger this official nor ask him for notification when approval is granted; it may hurt, rather than help, the contractor's cause.

2. Forwarding application to District Federal Reserve Bank. The contractor's bank or financing institution should take these papers to the Federal Reserve Bank in the district in which it is located.

3. Investigation and report to Federal Reserve Board in Washington. A representative of the Federal Reserve Bank will investigate the financial soundness of the loan and report the following facts to the Federal Reserve Board in Washington: (a) recommendation as to whether the guarantee should be made, (b) proportion of loan to be guaranteed. In making this investigation, he may call on the contractor and the firms with whom he does business.

4. Transmittal to appropriate government agency. The Federal Reserve Board in Washington will transmit this recommendation after review to the appropriate defense agency involved. If several agencies are involved, the guarantee, if approved, will be authorized by the agency having the greatest interest in the borrower's production. This is an important step, because the guaranteeing agency, not the Federal Reserve Board, is liable for any losses.

5. Approval and notification to Federal Reserve Board. The guaranteeing agency approves or turns down the loan, using as its guide the tests for eligibility previously mentioned and the risk involved, and notifies the Federal Reserve Board in Washington of its decision.

6. Notification by Federal Reserve Board to District Federal Reserve Bank. The Federal Reserve Board notifies the Federal Reserve Bank, which in turn notifies the financing agency and enters into a guarantee agreement.

7. Signing local bank agreement. The contractor signs the loan agreement with his bank, which recites that it is subject to the terms of a covering V Loan Guarantee Agreement.

8. Paying out funds. The contractor gets his money directly from his local bank, not from the government, as he needs it, up to the full amount of the loan agreement.

9. Paying back loan. Normally the contractor's loan agreement with his bank specifies that the proceeds of his defense contract (which he assigns to his bank) will be used to liquidate the loan.

\section{VI}

\section{Advance Payments}

As its name implies, payment in advance of the government's obtaining any title or receiving any performance is allowed both for prime contracts and sub- 
contracts of all types ${ }^{32}$ and can be used in addition to progress payments in the same contract. ${ }^{33}$

\section{A. Statutory Authority}

Because of the prohibition in 3 I U.S.C. section 529 against payments prior to the delivery of supplies or services to the government, statutory authority was required for advance payments, whether negotiated contracts ${ }^{34}$ or advertised procurements ${ }^{85}$ were involved.

\section{B. Interest}

Interest is charged by the government on advance payments at the rate of five per cent on the unliquidated balance, except for certain instances where interest-free advance payments are allowed to non-profit organizations, and so forth. ${ }^{30}$

\section{Uses}

Even though advance payments are listed last in the general order of preferences for financing mentioned in the regulations, ${ }^{37}$ there are nevertheless eight situations where advance payments are considered appropriate. These are for: ${ }^{38}$

r. Nonprofit contracts with nonprofit educational or research institutions.

2. Contracts solely for the management and operation of government-owned plants.

3. Contracts for acquisition of facilities at cost, for government ownership.

4. Contracts involving operations remote from financing institutions making suitable administration not possible.

5. Contracts of a highly classified nature.

6. Rare but essential contracts of financially over-extended contractors.

7. Contracts where reasonable guarantees or interest cannot be available.

8. Exceptional cases where advance payments will be more beneficial to the government than any other method.

\section{Steps}

The steps in advance payment disbursement fall into the following pattern: $:^{30}$

I. Funds belonging to the military department which approves the advance payment are deposited in a special bank account.

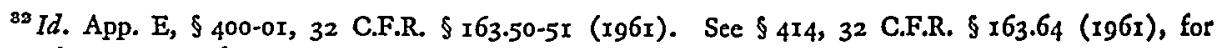
appropriate contract clause.

${ }^{38} I d$. App. E, $\S 402,32$ C.F.R. $\S 163.52$ (I96I); $\$ 408,32$ C.F.R. $\$ 163.58$ (196I).

34 70A Stat. I3I (x946), as amended, Io U.S.C. $\$ 2307$ ( 1958 ).

${ }^{35} 75$ Stat. 972 (I958), 50 U.S.C. \$ I 43I (Supp. IV I963).

${ }^{38}$ ASPR, App. E, $\$ 403,32$ C.F.R. $\$ 163.53$ (I96I); $\$ 414.2(6), 32$ C.F.R. $\$ 163.64-2(6)$ (Ig6r). But note that such interest is not allowed as a cost under any cost-reimbursement contract.

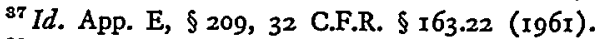

${ }^{38} I d$. App. E, $\$ 408,32$ C.F.R. $\$ 163.58$ (I96I). Also see $\$ 405,32$ C.F.R. $\$ 163.55$ (1961), for statutory requirements, and $\$ 409,32$ C.F.R. $\$ 163.59$ ( $196 \mathrm{x}$ ) for standards for advance payment determinations.

${ }^{80}$ Id. App. E, $\$ 4$ I 4.2, 32 C.F.R. $\$ 163.64-2$ (Ig6r). 
2. These funds may be withdrawn by the contractor prior to complete performance under a particular contract or contracts, for making payments for labor, materials, general and administrative overhead, and other expenses under the contract.

3. Checks must be signed by representatives of the contractor and the government.

4. As the contractor performs or delivers a part of the contract and would normally become entitled to contract payment, the advance payments are liquidated at a percentage specified in the advance payments clause. ${ }^{\mathbf{4 0}}$

\section{E. Security of Government}

The government does not take title to any property generated by the contractor in performance of the contract as security for advance payments, as in the case of progress payments, but adopts more conventional security methods such as a primary lien on the funds remaining in the special checking account, a paramount lien on property generated by the contractor in performance of the contract, or any other security type mortgage on all property owned by the contractor to the extent deemed necessary by the government. ${ }^{41}$

\section{VII}

\section{Accelerated Deprectation}

While the tax-free money which a firm accumulates as a result of depreciation is not technically a method of financing, the actual effect of financing exists; and a short discussion of depreciation is therefore pertinent herein.

During the war years, and for a short period thereafter, it was advantageous for a contractor to have a government contract because of the unusually rapid depreciation allowed under such contract, not allowed under normal industrial contracts. This difference no longer exists, but the new depreciation rules, open to all, should nevertheless prove particularly useful to government contractors.

\section{A. Former Certificates of Necessity}

Prior to December 3I, I959, ${ }^{42}$ defense agencies were authorized to issue so-called certificates of necessity, covering property used in defense contracts, which certificates allowed the contractor to depreciate such property over a shorter period of years than allowed for ordinary industrial contracts. The period was five years, which obviously was advantageous to a contractor who was attempting to accumulate tax free cash for use in his business more rapidly than allowed under the usual period which might be twenty years or more.

As changes to the Revenue Code over the years continued to liberalize the depreciation allowed to business generally, the need for special certificates diminished.

${ }^{10} I d$. App. E, $\$ 414.2(5), 32$ C.F.R. $\$ 163.64-2(5)$ (I96r).

${ }^{11}$ Id. App. E, $\S 414.2(6), 32$ C.F.R. $\S \mathrm{I} 63.64-2(6)$ (I96I).

12 INT. Rev. Code of I954, § I68(i), Pub. L. No. 85-165, 85th Cong., 2d Sess. (I957). 
As a result of this situation and for other technical reasons, the defense agencies for all practical purposes ceased issuing such certificates after December 3I, I959.

\section{B. Present Depreciation Schedules}

In 1962 the depreciation rules were further changed to allow more liberal depreciation. It is estimated that the new rules ${ }^{43}$ promulgated allow depreciation for machinery and equipment over a period averaging thirty per cent to forty per cent shorter than previously. Accordingly the four popular depreciation methods now available for use are: straight line method; double declining balance; sum of the years-digit method; one hundred fifty per cent declining balance method. The Revenue Act of $1962^{44}$ likewise provided a seven per cent investment credit, which also can result in a substantial increase in retained cash under appropriate conditions.

\section{VIII}

\section{Government-Furnished Tooling and Factitites}

When a contractor bids on a government contract it is expected that he usually will own or buy all of the necessary tooling and facilities himself. However, the government recognizes that in certain circumstances such tooling and facilities should be furnished by the government. Because this is an indirect method of financing, a short discussion of government-furnished tooling and facilities will be included herein.

\section{A. General}

Normally, and except where the contract provides otherwise, a contractor pays nothing for use of government-furnished tooling and facilities and except for advertised fixed-price contracts, the contractor is not responsible for loss or damage not due to his own negligence. The contractor is supposed to use the property only on government work, not on his private work.

\section{B. Regulations}

The rules for furnishing and use of government tooling and facilities are covered in a I00-page section of $\mathrm{ASPR},{ }^{45}$ together with two appendices. ${ }^{40}$

\section{Special Tooling}

The tooling which the government furnishes is not ordinary tooling but rather that type of jigs, dies, fixtures, and the like, that fall in the category of specialized items which a contractor normally would not use or need. ${ }^{47}$ If such tooling is available in government hands, and the cost of furnishing this is less than the cost to the

${ }^{43}$ Int. Rev. Ser. Pub. No. $456(7-62), 457$ (8-62).

4INT. Rev. CoDE of 1954, $\$ 38,76$ Stat. 962 (1962).

${ }^{45}$ ASPR I3, 32 C.F.R. $\$$ I3.100-13.506 (1961).

${ }^{4}$ ASPR Appendix B, "Manual for Control of Government Property in Possession of Contractors"; ASPR Appendix C, "Manual for Control of Government Property in Possession of Non-Profit Research and Development Contractors."

${ }^{47}$ ASPR 13-101.5, 32 C.F.R. \$ r3.101-5 (196r). 
government would be if the contractor had to buy his own special tooling, then this tooling will be furnished under the terms indicated later herein. ${ }^{48}$

\section{Facilities}

"Facilities" means such things as real property, buildings, structures, improvements and plant equipment. ${ }^{49}$ The government is less interested in furnishing facilities than it is tooling. These would be furnished when $:^{50}$

I. It is not possible to obtain contract performance without this.

2. Costs in excess of reasonable depreciation costs would result from contractor furnishing his own.

3. Lower costs for finished items would result.

4. It is otherwise in the best interests of the government.

\section{E. Contract Clauses}

Various clauses exist in ASPR which indicate the contractor's rights and responsibilities when the government furnishes property. Slight variations exist depending on the nature of the contract, but the following requirements found in the fixed price contract clause ${ }^{51}$ for supplies or services indicate the scope of the contractor's benefit and responsibilities:

I. The property will be "suitable for use" under the contract and will be delivered in time to enable the contractor to make delivery of items required by the contract.

2. Title to the property shall remain in the government.

3. The property shall be used only for the performance of the specific government contract.

4. A program of maintenance, or repair, protection and preservation of the property must be instituted by the contractor.

5. If an advertised contract, the contractor bears risk of loss or damage.

6. If a negotiated contract, the government bears risk of loss or damage except where contractor is at fault.

IX

Contractor Religf under Public Law 85-804

Another indirect financing method is the financial relief available through administrative action or so-called "contract adjustment boards" of the military departments, which formerly operated under title two of the First War Powers Act, but are now authorized under Public Law 85-804. ${ }^{52}$ To implement this new law, a separate

\footnotetext{
${ }^{8}$ ASPR I3-102.2, 32 C.F.R. $\S 13.102-2$ (196r).

${ }^{10}$ ASPR 13-101.6, 32 C.F.R. § I3.10I-6 (196r).

${ }^{50}$ ASPR 13-102.3, 32 C.F.R. \$ $13.102-3$ (196r).

"1 ASPR 13-502, 32 C.F.R. \$13.502 (I96I).

${ }^{12}$ Stat. 972 (1958), 50 U.S.C. \$ I $431-35$ (Supp. 1962).
} 
section in ASPR, section seventeen, has been issued, titled "Extraordinary Contractual Actions to Facilitate the National Defense."

While the mere fact of a loss occurring under a government contract does not itself form a sufficient basis for financial relief, under certain circumstances spelled out in ASPR, ${ }^{53}$ appropriate action, such as amendment without consideration, correction of a mistake or ambiguity in a contract, or formalization of an informal commitment, are allowed to alleviate financial problems of contractors by administrative or contract adjustment board action.

Contractors seeking relief file a request with the contracting officer, usually in letter form, stating all of the facts involved, and requesting the appropriate action desired. ${ }^{54}$

Whether a contractor's "appeal" is decided administratively, as section seventeen of ASPR also allows, ${ }^{55}$ or by submission to a contract adjustment board, ${ }^{50}$ it is carefully investigated in advance by the government agency involved. Board hearings when held are informal, and decisions rendered promptly.

\section{$\mathrm{X}$}

\section{SMall Business Loans}

\section{A. General}

Financing is also available from the Small Business Administration (SBA), ${ }^{\text {t7 }}$ or from privately-owned investment companies which are licensed and regulated by SBA. ${ }^{58}$ SBA loans are conditioned upon the non-availability of private financing, either in whole or in part, and must be of such sound value or so secured as reasonably to assure repayment. The maximum amount which SBA may loan is $\$ 350,000$, and the loan maturity cannot exceed ten years. The maximum interest rate is $5 \frac{1 / 2}{2}$ per cent, except that four per cent per annum is charged if at least fifty per cent of the net proceeds of the loan are to be utilized in redevelopment areas or in labor surplus areas. ${ }^{\text {59 }}$

\section{B. Small Business Administration Loans}

SBA may make a loan directly to the small business concern or it can do so in participation with a lending institution. Participation loans may be either immediate -i.e., SBA advancing immediately its portion of the loan-or on a guaranty basisi.e., the lending institution advancing the entire loan proceeds under an agreement with SBA whereby SBA will guarantee the institution an agreed portion of the loan. In all participation loans, the lending institution may charge an interest rate in excess

${ }^{63}$ ASPR 17-204, 32 C.F.R. $\$$ I7.204 (1961).

${ }^{5}$ ASPR I7-207, 32 C.F.R. $\$ 17.207$ (196r).

${ }^{6}$ ASPR 17-208.2, 32 C.F.R. \$ 17.208-2 (196r).

${ }^{80}$ ASPR 17-208.3, 32 C.F.R. \$ I7.208-3 (Ig6r).

${ }^{57} 72$ Stat. 387 (1958), 15 U.S.C. $\$ 636$ (Supp. 1962).

${ }^{58} 72$ Stat. 689 (1958), I5 U.S.C. \$ 66I (Supp. 1962).

${ }^{\circ}$ SBA's policies and rules governing its lending are published at 13 C.F.R., Parts 120 and 122 (1963). 
of $5^{1 / 2}$ per cent on its portion of the loan, provided that such interest rate does not exceed the local legal rate of interest or eight per cent per annum, whichever is less. The amount of the lending institution's participation is not included in computing the $\$ 350,000$ maximum which SBA may lend.

\section{Small Business Investment Company (SBIC) Loans}

Small Business Investment Companies may provide financing to government contractors by way of loans or in the form of equity capital. ${ }^{00}$ Such assistance is not directly from the government, but it is an indirect use of government funds and is intended as long-term financing. For this reason an SBIC cannot, except under special circumstances, make loans with less than a five year maturity. When it grants assistance, the SBIC may take assignments of government contracts and obtain the protection of the Assignment of Claims Act of 1940, as amended. ${ }^{61}$

The Small Business Investment Act of 1958 , as amended, also authorizes SBA to make long-term loans to state or to local development companies ${ }^{62}$-the loans to the latter being limited to "plant construction, conversion or expansion, including the acquisition of land" to assist an identifiable small business concern for a sound business purpose approved by SBA. ${ }^{63}$ Under SBA's regulations the development companies may re-lend part of the loan obtained from SBA to the identifiable small business concern for purposes approved by SBA, which is another indirect government financing method.

\section{Qualifying as a Small Business}

The rules for determining whether a concern qualifies as small business for the purposes of obtaining financial assistance from SBA or from a Small Business Investment Company differ from the rules applicable to determining small business size status for government procurement purposes. It is essential that prospective applicants for assistance consult the Small Business Size Standards Regulations, ${ }^{64}$ copies of which may be obtained at any SBA field office. ${ }^{65}$

\section{XI}

Area Redevelopment Act

The Area Redevelopment Act ${ }^{66}$ adopted by Congress in Ig6r "To establish an effective program to alleviate conditions of substantial and persistent unemployment and underemployment in certain economically distressed areas, ${ }^{, 67}$ is also of great

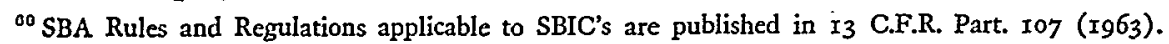

${ }^{01}$ Comp. Gen. Dec. No. B-152012, Aug. 6, 1963.

${ }^{02} 72$ Stat. 696,687 (1958), I5 U.S.C. $\$ 695,696$ (Supp. 1962). SBA's Rules and Regulations applicable to these loans are contained in I3 C.F.R. Part 108 ( 1963 ).

${ }^{03} 29$ Fed. Reg. 89 ( 1964 ).

os Ibid.

${ }^{\text {of }}$ An interesting discussion of these regulations as they apply to assistance from a Small Business Investment Company is contained in an article by Eugene J. Davidson, What Is a "Small Business Concern" Under the Small Business Investment Act of 1958?, 20 FED. B.J. 332 (1960).

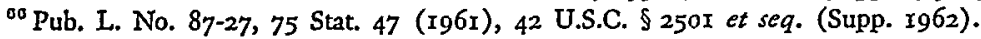

${ }^{07}$ Foreword to Pub. L. No. $87-27$, ibid. 
benefit to contractors who are doing government business but cannot find banking sources for long term low interest rate loans for fixed assets (such as land, buildings, machinery, and equipment). The contractor's plant must be physically located in an area determined to be a redevelopment area, ${ }^{88}$ but the law also allows loans to be made for rehabilitation or enlargement of existing plants ${ }^{60}$ in such areas.

Established within the Department of Commerce but having its own Administrator appointed by the President, ${ }^{70}$ the Area Redevelopment Administration (ARA) is authorized to make long term loans [up to twenty-five years] at relatively low cost interest rates [four per cent] for a relatively high proportion [up to sixty-five per cent] of the cost of fixed assets ${ }^{71}$ for businesses in redevelopment areas.

Applications are made through local ARA offices. After a preliminary review to determine feasibility, ARA in Washington forwards the application to SBA for processing, which includes a field study and recommendation. ARA then makes its determination to approve, modify, or deny the loan.

\section{Conclusion}

Normally a contractor who wants a defense contract must show, prior to award, that he is financially responsible. However, a contractor who is otherwise responsible can secure a defense contract which itself may provide financing, and can often secure government financing even after contract award.

Traditionally, contractors are expected to finance their own contracts from private banking sources, but when government financing is provided, the government prefers furnishing this by means of customary progress payments. If such is not possible under the facts, a government-guaranteed loan is the next preferred method, with unusual progress payments next in line of preference, and advance payments being the least favored of all.

In addition to government financing, a contractor can also ease his financial burdens by using the new government rules on accelerated depreciation, or secure government-furnished tooling and facilities. Under unusual circumstances, a form of financial relief may sometimes be made available under a special statute dealing with "extraordinary relief." Finally, but not the least important, is the governmentsponsored Small Business Administration loan, or financing from partially government-financed Small Business Investment Companies, which sources of financing are obviously only available to small businesses.

For firms newly established or existing in a so-called redevelopment area, a 196r Act of Congress provides long term, low interest rate loans for fixed assets. This law, while aimed primarily at alleviating chronic unemployment in certain areas of the country, is nevertheless another financing tool available to a government contractor.

${ }^{08} 75$ Stat. 48 (196x), 42 U.S.C. $\$ 2504$ (Supp. $x 962$ ).

${ }^{60} 75$ Stat. 50 (1961), 42 U.S.C. $\$ 2505$ (a) (Supp. 1962).

${ }^{70} 75$ Stat. 48 (196r), 42 U.S.C. $\$ 2502$ (Supp. 1962).

${ }^{71} 75$ Stat. 50 (1961), 42 U.S.C. $\$ 2505$ (b) (Supp. 1962). 